\title{
Variable effect of a large suspension-feeding bivalve on infauna: experimenting in a complex system
}

\author{
V. J. Cummings*, S. F. Thrush, J. E. Hewitt, G. A. Funnell \\ National Institute of Water and Atmospheric Research, PO Box 11-115, Hamilton, New Zealand
}

\begin{abstract}
In soft-sediment habitats there are many examples of species that modify their habitat and thus can be expected to have an important influence on macrobenthic community structure. The large, suspension-feeding pinnid bivalve Atrina zelandica adds complexity to soft-sediment habitats by protruding into the water column and altering boundary-flow conditions and by providing predation refuges and substrates for epifaunal settlement. To investigate effects of $A$. zelandica density on macrobenthic community composition, we conducted a density manipulation experiment in 4 different habitat types in and around Mahurangi Estuary, New Zealand. Our experiment incorporated a comparatively large spatial and temporal scale: each habitat was separated by at least $1.75 \mathrm{~km}$, and was sampled 3 times over $16 \mathrm{mo}$. Based on previous work, we predicted that macrofaunal community responses would differ between sites and would be stronger at sandy sites than muddy sites, and that variability in site hydrodynamic and sediment characteristics would help explain differences in benthic community responses to the density manipulation. While these predictions were supported, there was considerable temporal variation in the response. We also made predictions of the response of different aggregate macrofaunal groups to the A. zelandica manipulation (i.e. total numbers of individuals and taxa, suspension feeders, deposit feeders, top $2 \mathrm{~cm}$ dwellers, and mobile, short and long-lived species). Whether these predictions were supported varied spatially as well as temporally. To be able to generalise results, larger scale experiments, conducted at more than 1 site and at more than 1 time, are generally considered preferable. Although our A. zelandica manipulation experiment has these attributes, the results have demonstrated that the influence of this large suspension feeder on the associated macrofaunal community is not simple (except perhaps in sandy, relatively non-tidal environments), and illustrates our limited success in 'reducing' the complexity of this system using a field experiment. However, we were able to demonstrate that interactions between $A$. zelandica, site hydrodynamic conditions and sediment characteristics were all important in influencing macrofauna, rather than there being a simple A. zelandica density-macrofauna relationship. Thus, where multi-species interactions, indirect effects, non-linear biotic/abiotic interactions and threshold effects play an important role, specific experiments may not always lead to generalisable results, simply because the system is too complex.
\end{abstract}

KEY WORDS: Habitat modification · Atrina zelandica $\cdot$ Benthic communities $\cdot$ Density manipulation experiment $\cdot$ Soft-sediments

Resale or republication not permitted without written consent of the publisher

\section{INTRODUCTION}

Marine communities are structured by interactions between a large number of biotic and abiotic processes. These interactions occur at and across a range

*E-mail: v.cummings@niwa.cri.nz of different scales, resulting in highly complex systems. Much of our understanding of these systems has been generated by attempting to reduce this complexity (Levin 1988). Field experiments have proved to be powerful tools that allow us to test hypotheses about the importance of particular processes in influencing the structure and function of populations and communities. Ideally, the factor of interest is manipulated and

(C) Inter-Research 2001 
isolated from other potentially confounding factors to provide strong evidence of the importance of a particular process. In many ways experiments have become synonymous with rigour in benthic ecology. While field experiments have helped to elucidate the role of many biotic and abiotic processes, there is growing recognition of their limitations in addressing many important ecological questions (e.g. Raffaelli \& Moller 1999). There are potential problems with the design and interpretation of field experiments, as the relative importance of particular mechanisms will vary with the spatial and temporal scale of observation (e.g. Wiens et al. 1986, Irlandi et al. 1995, Irlandi 1996, Thrush et al. 1996, 1997a,b, Micheli 1997). In marine benthic systems, results of experiments may differ in time or space due to interactions with broader scale phenomena associated with habitat or oceanographic variability. For example, spatial variation in coastal upwelling has been shown to effect the nature of species interactions and food web connections in the rocky intertidal (Menge 1997); variability in oceanographic climate associated with El Niño has been shown to influence growth rates, species interactions and disturbance/ recovery dynamics in kelp forests (Dayton et al. 1999); and wave climate has been shown to influence adultjuvenile interactions in sandflat-dwelling depositfeeding bivalves (Thrush et al. 2000). Thus, the spatial and temporal scales chosen for each study will influence the ecological patterns actually observed (Dayton et al. 1992), and have a profound effect on the generality of the experimental results. Despite the recognised limitations of small-scale, single site/time experiments, the financial and logistical constraints involved in conducting experiments mean they are still common. To overcome the constraints of broad-scale replication, but still gain some insight into the generality of results, experimental sites can be arrayed along a gradient of variation in a broader scale process which is likely to influence experimental outcomes (Keddy 1991).

In soft-sediments, animals that may be expected to have an important influence on macrobenthic community structure are those that modify local habitat characteristics. There are many examples of species that modify their habitat through creation of subsurface burrows and galleries, by their physical presence at the sediment-water interface, or by affecting sediment micro-topography. Organisms that alter their physical habitat can affect water flow over the seabed (e.g. Eckman 1983, Witte et al. 1997, Green et al. 1998), thus indirectly changing resuspension rates (Woodin 1983). Organisms can also alter the biogeochemical composition of their surrounding sediments by deposition of faeces and pseudofaeces (Klerks et al. 1996, Prins et al. 1996, Peterson \& Heck 1999). Suspension-feeding bivalves are often considered a common example of habitat modifiers. They can have large-scale effects by depleting the water column of food and larvae, and influencing deposition and erosion processes by altering benthic boundary-layer flows (e.g. Dame 1992, Graf \& Rosenberg 1997, Graf 1999). The influence of suspension-feeding bivalves on benthic communities has been widely studied in soft-sediment environments (Olafsson et al. 1994) both using surveys and experimental manipulations. Their effects have ranged from positive to negative (Commito \& Boncavage 1989, Hines et al. 1989, Peterson \& Black 1993, Valentine \& Heck 1993, Warwick et al. 1997, Crooks 1998, Crooks \& Khim 1999, Ragnarsson \& Raffaelli 1999) or have been insignificant (Hunt et al. 1987, Black \& Peterson 1988). Typical of many field experiments, these studies all exploit small plot sizes but, collectively, they cover a wide range of habitat types.

In a survey of benthic communities found in and out of patches of a large suspension-feeding pinnid bivalve Atrina zelandica, macrofauna were influenced more by $A$. zelandica in a sandy site than in a muddy site (Cummings et al. 1998), while the opposite pattern was observed for nematode assemblages (Warwick et al. 1997). This highlights the potential variability in response, depending on habitat type and the type of organisms sampled. However, in these studies, the size and density of the A. zelandica, and the prevailing hydrodynamic conditions, varied between sites. Thus, to further investigate the influence of $A$. zelandica on macrobenthic community composition, we conducted a density-manipulation experiment in and around Mahurangi Harbour, New Zealand. Density treatments $\left(0,7.5,75\right.$ A. zelandica $\left.\mathrm{m}^{-2}\right)$ were chosen to contrast the effects of sediment erosion caused by turbulent flow amongst the $A$. zelandica (low-density treatment) and sediment deposition caused by skimming flow over the A. zelandica (high-density treatment). To determine the generality of the previous results and to investigate the role of habitat variability and differences in local species pools, the experiment was conducted at 4 different sites. Based on previous work, we predicted that our density manipulations would affect local macrobenthic community structure in the following ways: (1) macrofaunal community responses would differ between sites, and would be stronger at sandy sites than muddy sites (Cummings et al. 1998); (2) numbers of individuals and taxa would be greater in the control treatment (0 A. zelandica $\mathrm{m}^{-2}$; Cummings et al. 1998); (3) variability in hydrodynamic and sediment characteristics would help explain between-site differences in benthic community responses to the density manipulation (Green et al. 1998, Thrush et al. 1996, 2000). We also predicted that different functional groups of macrofauna would respond to A. zelandica density manipulations in the following ways: (4) deposit-feeder 
and mobile species abundances would increase with higher $A$. zelandica density (reflecting the higher food content due to A. zelandica biodeposits for both macrofaunal groups, and the added refuge from predators for the mobile species); (5) suspension-feeder abundance would decrease amongst $A$. zelandica, as a result of competing with these large bivalves for food; (6) responses of short-lived species (i.e. generation time $<1 \mathrm{yr}$ ) to density manipulations would be observed earlier than responses of long-lived species (i.e. generation time $>2 \mathrm{yr}$ ).

\section{MATERIALS AND METHODS}

Bivalve Atrina zelandica. A. zelandica is a large (up to $30 \mathrm{~cm}$ long) suspension-feeding pinnid bivalve common in sandy and muddy soft-sediment subtidal environs of north-eastern New Zealand (Morton \& Miller 1968, Powell 1979). A. zelandica protrudes above the sediment surface (commonly $7 \mathrm{~cm}$ ) and often forms large patches (e.g. $>10 \mathrm{~m}^{2}$ ) on the seafloor. These factors suggest that $A$. zelandica can have a considerable influence over local seston concentrations and near seabed hydrodynamics (Green et al. 1998). Further modification of the local habitat by A. zelandica can result from the production of organic-rich biodeposits which may provide a potential food source for other resident infauna. A. zelandica also adds to the complexity of its habitat by providing predation refuges and substrate for epifaunal attachment.

Site descriptions. The experiment was conducted on the east coast of the North Island, New Zealand (Fig. 1). Three sites were situated within Mahurangi Harbour, and 1 outside the harbour in Martins Bay (Fig. 1). Sites within the harbour encompassed different tidal current velocities, sediment types and benthic macroinvertebrate assemblages. Mid-tide water depth at the Martins Bay site was $7 \mathrm{~m}$ and ranged from 3 to $5 \mathrm{~m}$ at sites within the harbour. Sediment was predominantly fine to medium sands at the Martins Bay site (mean grain size $=134.04 \mu \mathrm{m}$ ), fine and medium sands and silt at the Mid Harbour site (mean grain size = $105.50 \mu \mathrm{m})$, and fine sand and silt at the Te Kapa and Upper Harbour sites (mean grain sizes $=61.00$ and $56.39 \mu \mathrm{m}$, respectively). Atrina zelandica was found naturally in the vicinity of all our experimental sites: inside the harbour it occurs in small to large patches (i.e. from several individuals to densities of 100 ind. $\mathrm{m}^{-2}$; patches up to $100 \mathrm{~m}$ in diameter), while outside the harbour in Martins Bay it forms 0.3 to $2 \mathrm{~m}$ wide, 2 to $10 \mathrm{~m}$ long patches (20 ind $\mathrm{m}^{-2}$ ) which are orientated perpendicular to the predominant wave direction. Within the har- bour, water flow is driven by semi-diurnal tides (max. velocities of 0.3 and $0.7 \mathrm{~m} \mathrm{~s}^{-1}$ at peak neap and spring tides, respectively), while in Martins Bay tidal flows are weak (max. velocity of $0.05 \mathrm{~m} \mathrm{~s}^{-1}$ ) and the water movement is dominated by wave activity during storms.

Experimental design. Study sites were established in the middle of bare sediment areas approximately $100 \mathrm{~m}$ in diameter. Natural Atrina zelandica patches occurred outside the bare sediment areas. An experimental plot consisted of a $2 \times 2 \mathrm{~m}$ area containing 1 of the following treatments: a control $\left(0 \mathrm{~A}\right.$. zelandica $\mathrm{m}^{-2}$ per plot; 0 A. zelandica $\mathrm{m}^{-2}$ ), a low-density (30 A. zelandica per plot; $7.5 \mathrm{~A}$. zelandica $\mathrm{m}^{-2}$ ) or a highdensity (300 A. zelandica per plot; $75 \mathrm{~A}$. zelandica $\mathrm{m}^{-2}$ ) treatment. Each treatment was replicated 4 times at each site. One replicate of each treatment was arranged in a block and blocks were positioned to minimise potential flow effects of 1 block on another (Fig. 2). The experimental plot size and the $A$. zelandica densities used were within the range of patches and densities occurring naturally at the sites.

The experiment was deployed from 21 to 25 November 1995. Atrina zelandica $(7.4 \pm 0.5 \mathrm{~cm}$ shell width) were collected from a single 'donor site' within the harbour (Fig. 1) using SCUBA, and were transplanted into the experimental plots within $1 \mathrm{~h}$ of collection. Average sizes of $A$. zelandica naturally occurring at each

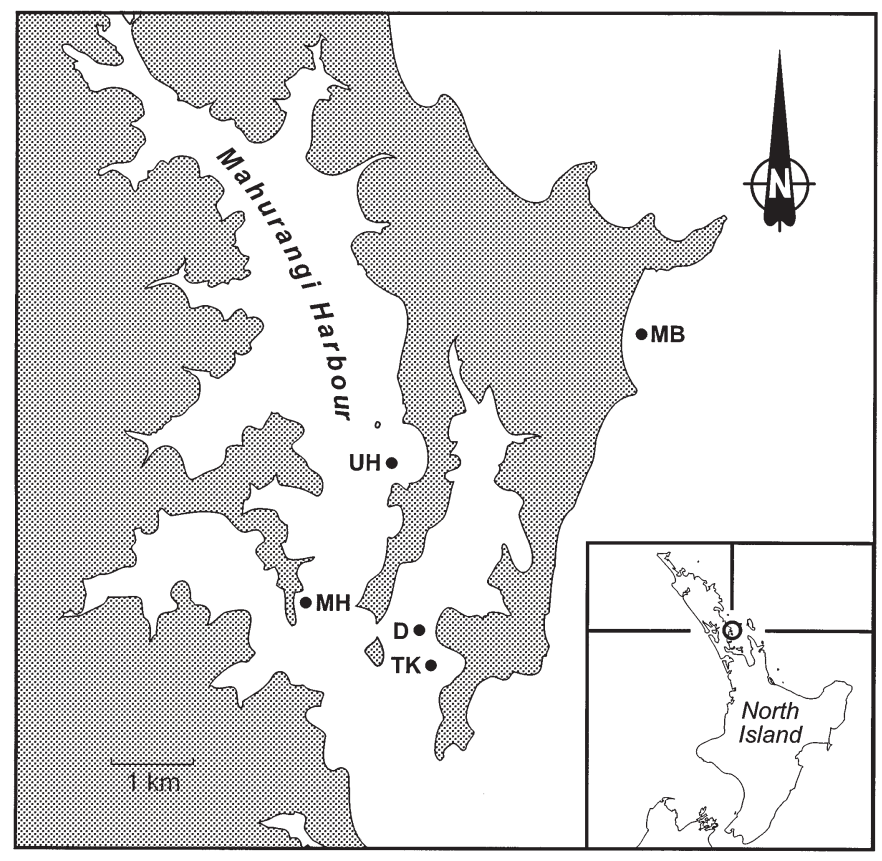

Fig. 1. Location of experimental sites in Mahurangi Harbour and Martins Bay. MB = Martins Bay; TK = Te Kapa; $\mathrm{MH}=$ Mid Harbour; $\mathrm{UH}=$ Upper Harbour; $\mathrm{D}=$ Atrina zelandica donor site 


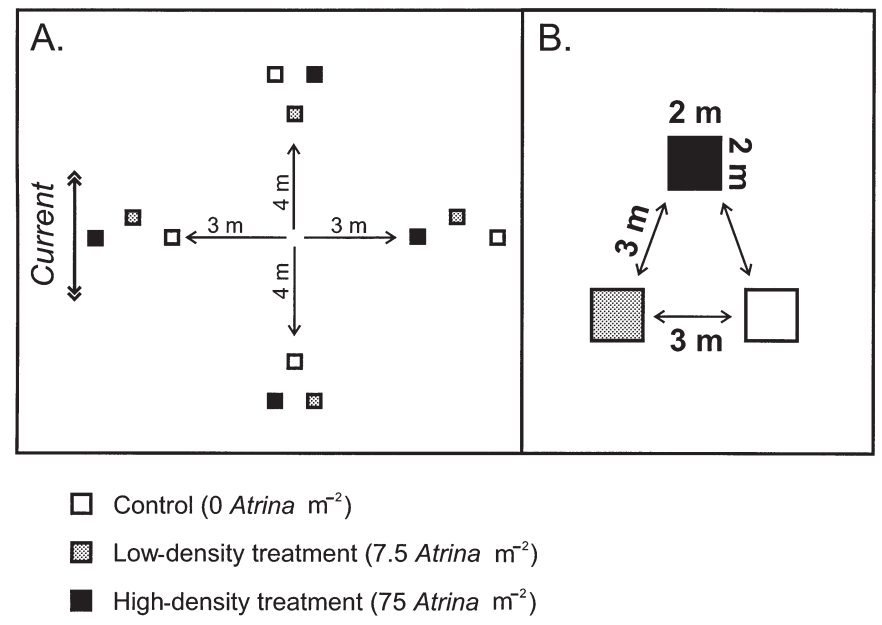

Fig. 2. (A) Arrangement of blocks at a site, and (B) the arrangement of experimental treatments within a block. Atrina $=A$. zelandica

site in January 1996 were $10.1 \mathrm{~cm}$ (Martins Bay), $9.8 \mathrm{~cm}$ (Te Kapa), $8.4 \mathrm{~cm}$ (Mid Harbour) and $8.7 \mathrm{~cm}$ (Upper Harbour). A. zelandica in the low- and highdensity treatments were arranged with nearest-neighbour distances of about 30 and $5 \mathrm{~cm}$, respectively. These are within the range of nearest-neighbour distances observed in natural A. zelandica patches (authors unpubl. obs.).

To isolate the effect of the physical presence of shells from the biological activity of the Atrina zelandica, an 'A. zelandica shell' treatment was included at the Te Kapa site. As our experiment focused on the effect of the live bivalves on macrofauna, this treatment was not established at every site. A. zelandica shells were obtained by collecting live individuals from the donor site, removing the flesh, and leaving the shells in air for at least $24 \mathrm{~h}$ before transplanting to the field site. A $2 \times$ $2 \mathrm{~m}$ plot containing 300 articulated A. zelandica shells arranged in 'real life' positions ( 75 shells $\mathrm{m}^{-2}$; an identical density to that of the high-density treatment) was established in each block.

Sampling. Plots were sampled 3 times over a 16 mo period: 18 to 20 January 1996, 17 to 20 September 1996 and 17 to 19 March 1997. On each occasion, 3 core samples $(10 \mathrm{~cm}$ diam., $13 \mathrm{~cm}$ deep) were collected within each plot and sieved through a $500 \mu \mathrm{m}$ mesh. Material retained on the mesh was preserved in $70 \%$ isopropanol and stained with $0.1 \%$ Rose Bengal. In the laboratory, macrofauna were sorted, identified and counted.

Atrina zelandica: To document changes in A. zelandica density during the experiment, the number of live individuals found in each of 3 randomly placed $50 \times 50 \mathrm{~cm}$ quadrats was recorded for each experimental plot.
Growth of Atrina zelandica during the experiment was assessed by measuring 5 randomly selected individuals in each plot from 2 of the blocks at each site in November 1995, and 5 randomly selected individuals in each plot in all blocks at the end of the experiment.

Environmental characteristics: To assess the environmental characteristics at each site during the experiment, sediment chlorophyll $a$, organic content and particle size, water temperature and salinity, and plaster block erosion were measured in all experimental plots in 2 orthogonal blocks at each site on each sampling occasion. A sediment core (2 cm diam., $2 \mathrm{~cm}$ deep) was collected for chlorophyll analysis. These cores were freezedried prior to analysis. Chlorophyll a was extracted by boiling this freeze-dried sediment in $95 \%$ ethanol, and the extract was processed using a spectrophotometer. An acidification step was used to separate degradation products from chlorophyll a (Sartory 1982). Surface sediment was collected by scraping, and subsequently analysed to determine organic content and sediment particle size. Organic content was estimated by drying the sediment at $90^{\circ} \mathrm{C}$ for $48 \mathrm{~h}$, then combusting in a muffle furnace for $3 \mathrm{~h}$ at $550^{\circ} \mathrm{C}$. Particle size was determined by digesting in $6 \%$ hydrogen peroxide for $48 \mathrm{~h}$ to remove organic matter, and dispersed using Calgon. A Galai particle analyser (Galai Cis-100; Galai Productions Ltd., Midgal Haemek, Israel) was then used to calculate \% volumes for the medium sand, fine sand, silt and clay fractions. An estimate of relative water flow was obtained by deploying plaster blocks $2 \mathrm{~cm}$ above the sediment surface (see Commito et al. 1995 and Cummings et al. 1998 for detailed methods). Blocks were deployed slightly above the sediment surface to avoid abrasion from sediment moving along the sedimentwater interface with the bedload. Blocks were deployed for 17 to $26 \mathrm{~h}$, and the weight loss $\left(\mathrm{g} \mathrm{h}^{-1}\right)$ was corrected for differences in water temperature and salinity between sampling times (Howerton \& Boyd 1992, Thompson \& Glenn 1994). Plaster blocks were not deployed at the Te Kapa site in September 1996.

Statistical analyses: Analyses of whether the transplanted Atrina zelandica densities were maintained and whether any differential growth occurred at each site over the course of the experiment were performed within a generalised linear modelling framework (McCullagh \& Nelder 1989, Crawley 1993) using SAS/ Insight (1993). Model fit was evaluated by visual inspection of half-normal plot residuals and plots of residuals versus predicted values. Where the model fit was questionable, a model with a Poisson error structure and a log link function was run and again evaluated for fit. In no case did we need to investigate fur- 
ther error-type options. For the live A. zelandica density data, a model with a normal error structure and an identity link function was run on a data set containing all site and sampling date data, with site, date and treatment as non-random factors, block as a random factor, and site $\times$ treatment, date $\times$ treatment and date $\times$ site as interaction terms (i.e. a standard 2-way ANOVA model). As significant interaction terms were found, analyses were continued on each date separately, and the $\mathrm{p}$ values were adjusted for the number of dates tested (i.e. 3) using the Bonferroni correction. Differential growth of $A$. zelandica between sites and treatments over the duration of the experiment was also investigated in this way, using size data from the last sampling occasion (March 1997), with treatment and site as fixed factors, block as a random factor and a treatment $\times$ site interaction term.

The effect of Atrina zelandica on the physical environment was also investigated. As we had only a single measurement from each treatment in each of 2 blocks on each sampling occasion, we were restricted to pairwise comparisons between each treatment and the control. Differences between the control and treatment plots were calculated for each physical variable (i.e. \% organic content, chlorophyll $a_{1} \%$ volume silt, \% volume clay and plaster block weight loss) for the 2 blocks on each sampling occasion. A 2-sided Wilcoxon signrank test $(\alpha=0.05)$ was then used to determine whether this difference was significantly different from zero for the low $A$. zelandica density-control and the high $A$. zelandica density-control differences separately. Initially the differences were tested over all sites and sampling occasions; where a non-significant result occurred the analysis was then conducted separately for each site, as it was apparent that sites were sometimes behaving differently.

Benthic community responses were investigated using correspondence analysis (CANOCO: ter Braak 1986, ter Braak \& Prentice 1988) on the raw data with down-weighting of rare species (Hill 1979). ANOVAtype hypothesis testing was carried out following Legendre \& Anderson (1999), using factor and interaction terms coded as dummy variables in the production of canonical ordination axes. The significance of each term was assessed by testing the significance of the first canonical eigenvalue, using 999 random calculations. We tested for 3-way and 2-way interaction terms involving treatments, using all sites, dates, treatments, blocks and replicates. As all of these were significant $(p<0.05)$ and as the ordination plots of the correspondence analysis suggested stronger site than date differences, individual sites were then analysed separately. Interaction terms in these analyses included block, date and treatment. As all sites exhibited either a significant 3-way interaction or a significant date $\times$ treatment interaction term, further analyses were conducted on the effect of treatment on each sampling date within each site.

Multivariate analysis of community effects was followed by univariate analyses of measures of diversity and the numbers of individuals in some aggregate groupings of taxa. Diversity indices (i.e. number of individuals, $n_{i}$ number of taxa, S) were calculated using PRIMER (Clarke 1993). Numbers of individuals in the following aggregate macrofauna groups were analysed: deposit feeders, suspension feeders, mobile species, short-lived species (generation time $<1 \mathrm{yr}$ ) and long-lived species (generation time $>2 \mathrm{yr}$ ). These univariate analyses were performed within a generalised linear modelling framework, as described above for the live Atrina density and growth data. As all variables exhibited either significant 3 -way or site $\times$ treatment interaction terms, analyses were continued on each site separately. Where either significant block $x$ date $\times$ treatment or date $\times$ treatment interaction terms were found, analyses were continued on each date separately and $p$ values were adjusted for the number of dates tested (i.e. 3) using the Bonferroni correction. If a significant block $\times$ treatment interaction and $a$ treatment effect were found, the data were examined to see if the treatment effect was consistent in direction over blocks. If not, the treatment effect was not considered to be significant. Dominant taxa at each site (i.e. abundances of $\geq 2$ individuals per core on $>1$ occasion) were also analysed, although on a site-by-site basis. For the Te Kapa site, 1 further analysis was run incorporating data from the Atrina zelandica shell treatment, to help distinguish biological versus physical effects of $A$. zelandica. The low-density A. zelandica treatment data was replaced by the $A$. zelandica shell treatment data. This was done because the density used in the A. zelandica shell treatment was the same as that used in the high-density $A$. zelandica treatment, and we were most interested in whether the A. zelandica shell treatment was more like the highdensity $A$. zelandica treatment or the control. This approach also meant that the power of detecting differences between the treatments would be unaffected by different degrees of freedom. Differences in the diversity indices, aggregate macrofauna groups and abundant taxa were then investigated as described above.

Finally, we investigated the use of environmental covariables for removing significant interaction terms in the multi-site ANOVAs. Previous research identified an effect of Atrina zelandica on water flow which could be expected to be different depending on velocity and flow type (i.e. tidally driven versus wave orbital; Green et al. 1998). This effect of A. zelandica on flow characteristics, both within the $A$. zelandica bed and on ben- 
thic boundary-layer development, could be expected to elicit differences in benthic macrofauna responses to A. zelandica. The following measures of flow characteristics were therefore included as covariables: (1) water flow within the experimental plots (as measured by plaster block weight loss); (2) maximum velocity (depth and tidally averaged for a spring tide; derived for each site from a layered 3-dimensional hydrodynamic model of Mahurangi Harbour and the surrounding area; Oldman \& Black unpubl. data); (3) horizontal turbulence, an index of turbulence created by water flow around (but not over) an $A$. zelandica (calculated by multiplying the average shell width of $A$. zelandica in a plot by maximum water velocity); (4) roughness element density $(\Lambda)$ (Nowell \& Church 1979), a measure of bed roughness $\Lambda=N A_{\mathrm{e}} /$ $A_{\mathrm{t}}$, where $N=$ number of roughness elements (i.e. $A$. zelandica density), $A_{\mathrm{e}}=$ plan area of individual roughness elements (i.e. A. zelandica width $\times 2 \mathrm{~cm}$ [where 2 $\mathrm{cm}$ is the typical $A$. zelandica thickness at the top of the shell]) and $A_{\mathrm{t}}=$ total area of plot (values $>0.1$ reflect skimming flow conditions; Green et al. 1998); (5) seabed drag coefficient $\left(C_{100}\right)$, a measure of the interaction between flow and benthic roughness elements, and thus a reflection of the mean-flow energy dissipated in the benthic boundary layer by turbulence. For $\Lambda>0.1$ or $\Lambda=0, C_{100}$ was calculated by Green et al. (1998) using the $k$ roughness formula:

$$
C_{100}=\left[\frac{\kappa}{\ln (3000 / m k \lambda)}\right]^{2}
$$

where $\kappa=$ Von Karmans constant, $m=100, k=$ height A. zelandica protrudes above the bed $(7 \mathrm{~cm})$ and $\lambda=$ aerial concentration of $A$. zelandica.

As initial statistical analyses demonstrated changes in Atrina zelandica density and size in the experimental plots both over the course of the experiment and between sites, the number of live bivalves per treatment, and average bivalve size were included as covariables. Sediment chlorophyll a content, organic content and median particle size were also included, as we expected changes within the plots as a result of changes to flow characteristics and $A$. zelandica biodeposition. Site depth and sampling date were also added to the list of environmental covariables.

Canonical correspondence analysis (CCA) was used to relate macrofaunal community composition to the above environmental covariables on each sampling date. The important variables were selected using forward selection and the overall model was tested for significance of the eigenvalues using the unrestricted permutation test given in CANOCO (Verdonschot \& ter Braak 1994). Unfortunately, backwards selection (probably the more appropriate method for investigation of these relationships) is not yet available in
CANOCO. The effectiveness of the explanatory variables in each of these analyses (or percent variance explained) was determined by dividing the sum of the canonical eigenvalues by the overall sum of the eigenvalues from the correspondence analysis (ter Braak \& Verdonschot 1995). The model was also tested for dependence on the initial variable selected by the forward selection method by using a number of different starting variables.

The response of the diversity and aggregate macrofauna groups to each environmental covariable was examined graphically to identify non-linear responses (e.g. logarithmic, exponential, polynomial). Some logarithmic and second-order polynomial responses were identified. Logarithmic and polynomial responses were treated by log transformation and introducing a square term, respectively. Significant covariables were then identified by backwards regression, with an exit criteria of $p=0.15$ (Crawley 1993). After this process had been completed, the effect of co-linearity on the resultant regression was tested by dropping co-linear terms (identified by high variance inflation factors) one at a time and looking for changes to both the significance of the variable and the sign of the effect.

\section{RESULTS}

\section{Bivalve Atrina zelandica}

The number of live Atrina zelandica recorded in the low- and high-density treatments decreased over the experimental period. However, there were always significant differences between treatments at a site $(\mathrm{p}<$ 0.05). By March 1997, numbers of live A. zelandica in the high-density treatments ranged from $92.00 \pm 28.23$ to $56.00 \pm 21.45$ (mean number of individuals per plot $\pm \mathrm{SD}$; recorded at Martins Bay and Upper Harbour, respectively), while the low-density treatments contained from $20.00 \pm 8.98$ to $14.50 \pm 6.76$ individuals (also recorded at Martins Bay and Upper Harbour, respectively). The average shell width of $A$. zelandica when initially transplanted was $7.4 \pm 0.5 \mathrm{~cm}$. By the end of the experiment there were significant differences in the average size of $A$. zelandica between sites $(\mathrm{p}=0.0001)$. A. zelandica were largest at Martins Bay $(10.7 \pm 0.9 \mathrm{~cm})$ and smallest at Upper Harbour $(8.4 \pm$ $0.8 \mathrm{~cm})$.

\section{Environmental characteristics}

The range of values for the environmental variables recorded in the control plots at each site over the experiment are given in Table 1. Environmental char- 
Table 1. Range of values for environmental variables in control plots at each site over the experiment

\begin{tabular}{|c|c|c|c|c|}
\hline Variable & Martins Bay & Mid Harbour & Te Кара & Upper Harbour \\
\hline$\%$ Organic content & $0.8-2.2$ & $1.3-2.6$ & $1.6-3.5$ & $1.8-5.0$ \\
\hline Chlorophyll a (mg g $\left.{ }^{-1}\right)$ & $0.006-0.892$ & $0.0001-0.0325$ & $0.005-0.0569$ & $0.004-0.0899$ \\
\hline \% Clay & $1.4-2.7$ & $1.8-4.1$ & $3.7-6.1$ & $4.2-6.5$ \\
\hline$\%$ Silt & $10.3-18.1$ & $16.5-32.1$ & $37.9-57.1$ & $47.4-66.3$ \\
\hline$\%$ Fine sand & $23.1-36.3$ & $21.9-35.6$ & $34.7-46.8$ & $22.2-31.9$ \\
\hline$\%$ Medium sand & $46.5-60.5$ & $35.7-54.7$ & $4.5-10.9$ & $5.0-14.7$ \\
\hline Plaster block wt loss $\left(\mathrm{g} \mathrm{h}^{-1}\right)$ & $0.03-0.52$ & $0.10-0.58$ & $0.08-0.51$ & $0.08-0.49$ \\
\hline
\end{tabular}

Table 2. Results of 2-sided Wilcoxon sign-rank tests $\left(\sum \mathrm{R}_{\mathrm{i}}\right)$ on environmental covariables. Tests were initially conducted over all sites; where a non significant result occurred, analysis was then conducted separately for each site. For the 'Over all sites' test, reject $H_{\mathrm{o}}$ (differences zero) if $\sum \mathrm{R}_{\mathrm{i}}<82$ or $\sum \mathrm{R}_{\mathrm{i}}>218$; for the individual site tests, reject $H_{\mathrm{o}}$ if $\sum \mathrm{R}_{\mathrm{i}}<3$ or $\sum \mathrm{R}_{\mathrm{i}}>18$; alpha $=0.05$. C = control $\left(0\right.$ Atrina zelandica $\left.\mathrm{m}^{-2}\right) ; \mathrm{L}=$ low-density $\left(7.5 \text { A. zelandica } \mathrm{m}^{-2}\right)_{;} \mathrm{H}=$ high-density $\left(75 \mathrm{~A}\right.$. zelandica $\left.\mathrm{m}^{-2}\right)$

\begin{tabular}{|c|c|c|c|c|c|}
\hline Environmental covariable & Over all sites & Martins Bay & Mid Harbour & Te Кара & Upper Harbour \\
\hline \multicolumn{6}{|l|}{$\%$ Organic content } \\
\hline $\mathrm{L}$ & $219 \mathrm{~L}>\mathrm{C}$ & & & & \\
\hline $\mathrm{H}$ & 171 & $18 \mathrm{H}>\mathrm{C}$ & 17 & 11 & 6 \\
\hline \multicolumn{6}{|l|}{ Chlorophyll a (mg g $\left.{ }^{-1}\right)$} \\
\hline $\mathrm{L}$ & 115 & $0 \mathrm{C}>\mathrm{L}$ & $20 \mathrm{~L}>\mathrm{C}$ & 6 & 5 \\
\hline $\mathrm{H}$ & 169 & $3 \mathrm{C}>\mathrm{H}$ & $20 \mathrm{H}>\mathrm{C}$ & 6 & 16 \\
\hline \multicolumn{6}{|l|}{ \% Clay } \\
\hline $\mathrm{L}$ & 186 & 12 & 20 & 10 & 12 \\
\hline $\mathrm{H}$ & 177 & $18 \mathrm{H}>\mathrm{C}$ & 15 & 10 & 8 \\
\hline \multicolumn{6}{|l|}{$\%$ Silt } \\
\hline $\mathrm{L}$ & $227 \mathrm{~L}>\mathrm{C}$ & & & & \\
\hline $\mathrm{H}$ & 165 & $20 \mathrm{H}>\mathrm{C}$ & 15 & 11 & $3 \mathrm{C}>\mathrm{H}$ \\
\hline \multicolumn{6}{|l|}{ Plaster block wt loss $\left(\mathrm{g} \mathrm{h}^{-1}\right)$} \\
\hline L & 147 & 12 & 8 & 14 & 13 \\
\hline $\mathrm{H}$ & $60 \mathrm{C}>\mathrm{H}$ & & & & \\
\hline
\end{tabular}

acteristics varied between treatments, sites and sampling occasions. Sediment organic content was generally highest at Upper Harbour and lowest at Martins Bay (Table 1). There was significantly less organic matter in the control treatments than in the the lowdensity treatments over all sites (Table 2), and in the control plots than in the high-density treatments at Martins Bay only (Table 2). Sediment chlorophyll a content was highest in March 1997 at all sites (p < 0.05), ranging from 0.005 to $0.020 \mathrm{mg} \mathrm{g}^{-1}$ in January 1996, 0.001 to $0.010 \mathrm{mg} \mathrm{g}^{-1}$ in September 1996, and 0.300 to $1.400 \mathrm{mg} \mathrm{g}^{-1}$ in March 1997. Generally, chlorophyll a was higher at Martins Bay and Upper Harbour than at Mid Harbour and Te Kapa (Table 1). Significantly more chlorophyll a was detected in the control-plot sediments than in the low- or high-density treatment sediments at Martins Bay, while the opposite pattern was observed at Mid Harbour (Table 2). Sediment \% clay content was highest at Te Kapa and Upper Harbour (Table 1). There was significantly less clay in the control plots than in the high-density Atrina zelandica treatment at Martins Bay only (Table 2). The $\%$ silt content was also lower in the control plots than in the low-density treatments over all sites; however, comparisons of the high-density and control treatments showed different effects at Martins Bay than at Upper Harbour (Table 2). Plaster block erosion was greatest in January 1996 at all sites; no site showed more or less erosion than another site on any sampling date. Over all sites, the plaster blocks deployed in the control plots eroded faster than those in the high-density treatments (Table 2).

\section{Community composition}

Correspondence analysis showed no consistent community response to the experimental treatments over all sites and sampling dates (site $\times$ date $\times$ treatment, $\mathrm{p}<$ 0.05 ), at individual sites over all sampling dates (date $x$ treatment, $\mathrm{p}<0.05$ ), or on each sampling date over all sites (site $\times$ treatment, $\mathrm{p}<0.05$ ). Fig. 3 shows the tra- 




Fig. 3. Atrina zelandica. Ordination plot of untransformed macrofauna community data for each site on each sampling date produced by correspondence analysis. Points are connected in time sequence. Axis 1 explains $15.4 \%$ and Axis 2 explains $11.1 \%$ of variability in community data. Inset shows temporal trajectories of community change at Te Kapa and Upper Harbour sites in more detail. Control $=0 \mathrm{~A}$. zelandica $\mathrm{m}^{-2}$; Low-density Atrina $=7.5$ A. zelandica $\mathrm{m}^{-2}$; High-density Atrina $=75$ A. zelandica $\mathrm{m}^{-2}$

jectories of change in community composition during the experiment for each site. The Martins Bay community showed the greatest variation over the experimental period, followed by Mid Harbour. The temporal trajectories of the high-density treatments at these sites were similar. Conversely, Te Kapa and Upper Harbour showed relatively little temporal variation in community composition. Community differences between treatments generally increased as the experiment progressed at each site (Fig. 3).

\section{Community descriptions}

Martins Bay and Mid Harbour were dominated by small crustaceans (i.e. amphipods, ostracods and tanaids). Small bivalves were also common (i.e. Montacuta sp. [commensal with the heart urchin, Echinocardium edule] at Martins Bay; Theora lubrica, Arthritica bifurca and Nucula spp. at Mid Harbour); polychaetes were rare amongst the dominant taxa at these sites. Te Kapa and Upper Harbour were dominated by bivalves (i.e. T. lubrica, A. bifurca and Nucula spp.) and polychaetes (i.e. Cossura sp., Aricidea sp., Boccardia syrtis and Paraonis sp.), with relatively few small crustaceans (although phoxocephalid amphipods were common on most sampling dates at Te Kapa). With the exception of phoxocephalids, which were amongst the dominant taxa at all sites, there is an appreciable difference in the macrobenthic community structure between sites (Table 3).

Only phoxocephalid amphipods and tanaids exhibited differences between treatments at more than 1 site (Table 4). Significantly more phoxocephalids were found in the control plots than in the high-density treatments in January 1996 at Martins Bay and Te Kapa (Table 4). Tanaids were most common in the lowdensity Atrina zelandica treatment on 2 sampling occasions at Martins Bay, while at Mid Harbour they were most abundant in the control plots in September 1996 (Table 4). The bivalve Theora lubrica, the small crustaceans Gynodiastylis laevis and ostracod sp. 1, and the polychaetes Boccardia syrtis and Aricidea sp. all exhibited significant differences in abundance between treatments at 1 site on 1 sampling occasion (Table 4). The bivalve Montacuta sp. was common at Martins Bay on all sampling dates (Table 3), but showed no significant difference in abundance between treatments (Table 4). There were more significant differences between treatments on the January 1996 sampling occasion, when there were slightly more incidences of high $A$. zelandica densities depressing abundances of taxa (Table 4).

\section{Diversity indices}

The numbers of individuals collected were higher at Martins Bay and Mid Harbour than at the remaining sites (Fig. 4). Significant treatment effects were detected at Martins Bay only, where fewer individuals were found in the high-density Atrina zelandica plots than the remaining treatments over all sampling dates, and where more taxa were found in the low-density $A$. zelandica plots in January 1996 only (Fig. 4).

\section{Aggregate macrofauna groups}

Numbers of individuals in each of the aggregate groups (except the long-lived species) were highest in January 1996 at Martins Bay (Fig. 5). The majority of significant differences between treatments were also detected at Martins Bay and, without exception, lower abundances were found amongst the high-density Atrina zelandica plots than in the control plots at this site (Fig. 5). The same pattern was observed at Te Kapa for short-lived species in January 1996. For mobile species at Te Kapa in September 1996, the opposite abundance pattern was observed; i.e. significantly more individuals were found in the high-density A. zelandica treatments than the control plots (Fig. 5). There were no significant differences in the abundances of long-lived species between treatments at any site on any sampling date. 
Table 3. Top 5 ranked taxa at each site, and their mean abundances \pm SE per core, found in each experimental treatment on each sampling date

\begin{tabular}{|c|c|c|c|c|c|c|c|c|}
\hline Date & \multicolumn{2}{|l|}{ Control } & \multicolumn{2}{|c|}{ Low-density Atrina zelandica } & \multicolumn{2}{|c|}{ High-density A. zelandica } & \multicolumn{2}{|c|}{ A. zelandica shell } \\
\hline \multicolumn{9}{|c|}{ Martins Bay } \\
\hline Jan & Ostracod sp. 3 & $56.17 \pm 6.65$ & Ostracod sp. 3 & $51.00 \pm 7.64$ & Ostracod sp. 3 & $40.00 \pm 7.86$ & & \\
\hline \multirow[t]{4}{*}{1996} & Phoxocephalidae & $10.83 \pm 1.45$ & Montacuta sp. & $19.58 \pm 10.2$ & Tanaids & $6.58 \pm 2.02$ & & \\
\hline & Gynodiastylis laevis & s $7.25 \pm 1.24$ & Phoxocephalidae 1 & $12.33 \pm 1.92$ & Montacuta sp. & $6.33 \pm 1.94$ & & \\
\hline & Nucula spp. & $4.58 \pm 1.20$ & Tanaids & $8.00 \pm 0.98$ & Phoxocephalidae & $3.17 \pm 0.67$ & & \\
\hline & Montacuta sp. & $4.00 \pm 1.30$ & Gynodiastylis laevis & $s 5.83 \pm 1.65$ & Minuspio sp. & $1.83 \pm 0.59$ & & \\
\hline Sep & Ostracod sp. 2 & $17.67 \pm 3.89$ & Ostracod sp. 2 & $19.75 \pm 6.73$ & Ostracod sp. 2 & $9.92 \pm 3.04$ & & \\
\hline \multirow{3}{*}{1996} & Montacuta sp. & $10.42 \pm 6.22$ & Montacuta sp. & $6.92 \pm 3.88$ & Montacuta sp. & $4.08 \pm 2.99$ & & \\
\hline & Sabellidae & $2.00 \pm 1.35$ & Gynodiastylis laevis & $s 0.67 \pm 0.36$ & Ostracod sp. 1 & $1.25 \pm 0.46$ & & \\
\hline & Ostracod sp. 1 & $1.92 \pm 0.83$ & Tanaids & $0.67 \pm 0.31$ & & & & \\
\hline Mar & Montacuta sp. & $10.75 \pm 4.89$ & Ostracod sp. 4 & $4.67 \pm 1.19$ & Prionospio sp. & $3.50 \pm 0.75$ & & \\
\hline \multirow[t]{4}{*}{1997} & Ostracod sp. 4 & $10.33 \pm 3.24$ & Montacuta sp. & $4.08 \pm 1.25$ & Phoxocephalidae & $3.33 \pm 0.99$ & & \\
\hline & Phoxocephalidae & $5.17 \pm 1.09$ & Prionospio sp. & $3.83 \pm 2.28$ & Ostracod sp.6 & $1.17 \pm 0.42$ & & \\
\hline & Anthuridae & $2.92 \pm 1.01$ & Phoxocephalidae & $3.00 \pm 0.79$ & Ostracod sp. 4 & $1.08 \pm 0.50$ & & \\
\hline & Polydorid & $2.25 \pm 0.73$ & Anthuridae & $2.50 \pm 1.06$ & Minuspio sp. & $0.92 \pm 0.36$ & & \\
\hline \multicolumn{9}{|c|}{ Mid Harbour } \\
\hline Jan & Ostracod sp. 1 & $4.50 \pm 0.69$ & Ostracod sp. 2 & $3.00 \pm 2.92$ & Ostracod sp. 1 & $10.75 \pm 2.04$ & & \\
\hline \multirow[t]{5}{*}{1996} & Phoxocephalidae & $3.75 \pm 0.79$ & Tanaids & $2.25 \pm 0.76$ & Phoxocephalidae & $4.25 \pm 0.69$ & & \\
\hline & Ostracod sp. 2 & $2.25 \pm 0.81$ & Paracalliopidae & $2.00 \pm 0.23$ & Paracalliopidae & $3.50 \pm 1.79$ & & \\
\hline & Nucula spp. & $1.75 \pm 0.23$ & Ostracod sp. 1 & $1.75 \pm 1.03$ & Nucula spp. & $1.50 \pm 0.24$ & & \\
\hline & Tanaids & $1.25 \pm 0.44$ & Phoxocephalidae & $1.50 \pm 0.63$ & Arthritica bifurca & $1.25 \pm 0.34$ & & \\
\hline & & & & & Ostracod sp. 2 & $1.25 \pm 0.82$ & & \\
\hline Sep & Phoxocephalidae & $5.25 \pm 1.15$ & Ostracod sp. 2 & $6.25 \pm 3.03$ & Ostracod sp. 1 & $7.25 \pm 1.50$ & & \\
\hline \multirow{4}{*}{1996} & Ostracod sp. 2 & $3.50 \pm 5.07$ & Ostracod sp. 1 & $3.00 \pm 0.59$ & Ostracod sp. 2 & $3.50 \pm 5.07$ & & \\
\hline & Tanaids & $2.00 \pm 1.86$ & Theora lubrica & $2.75 \pm 1.96$ & Phoxocephalidae & $3.00 \pm 0.84$ & & \\
\hline & Ostracod sp.7 & $1.75 \pm 0.86$ & Anthuridae & $2.50 \pm 0.81$ & Theora lubrica & $2.25 \pm 1.39$ & & \\
\hline & Ostracod sp. 1 & $1.50 \pm 0.91$ & Phoxocephalidae & $2.00 \pm 0.81$ & Phylo sp. & $0.75 \pm 0.30$ & & \\
\hline Mar & Phoxocephalidae & $1.50 \pm 0.61$ & Phoxocephalidae & $4.00 \pm 0.86$ & Ostracod sp. 1 & $3.00 \pm 0.99$ & & \\
\hline \multirow[t]{5}{*}{1997} & Ostracod sp. 1 & $1.50 \pm 0.34$ & Talitridae & $3.25 \pm 1.08$ & Theora lubrica & $2.25 \pm 0.71$ & & \\
\hline & Ostracod sp. 5 & $1.00 \pm 0.28$ & Ostracod sp. 1 & $2.00 \pm 0.54$ & Phoxocephalidae & $1.25 \pm 0.51$ & & \\
\hline & Arthritica bifurca & $0.75 \pm 0.71$ & Ostracod sp. 5 & $1.75 \pm 0.56$ & Nucula spp. & $1.00 \pm 0.28$ & & \\
\hline & Nucula spp. & $0.75 \pm 0.24$ & Macomona liliana & $0.75 \pm 0.58$ & & & & \\
\hline & & & Theora lubrica & $0.75 \pm 0.34$ & & & & \\
\hline \multicolumn{9}{|c|}{ Te Кара } \\
\hline Jan & Phoxocephalidae & $4.00 \pm 0.72$ & Boccardia syrtis & $3.25 \pm 1.06$ & Cossura sp. & $2.00 \pm 0.34$ & Phoxocephalidae & $2.50 \pm 0.74$ \\
\hline \multirow[t]{4}{*}{1996} & Boccardia syrtis & $3.50 \pm 0.75$ & Phoxocephalidae & $2.00 \pm 0.58$ & Paraonis sp. & $1.25 \pm 0.61$ & Paraonis sp. & $2.25 \pm 0.41$ \\
\hline & Ostracod sp. 1 & $2.50 \pm 0.28$ & Paraonis sp. & $2.00 \pm 0.45$ & Nucula spp. & $1.00 \pm 0.52$ & Phylo sp. & $1.25 \pm 0.31$ \\
\hline & Paraonis sp. & $2.25 \pm 0.58$ & Cossura sp. & $1.25 \pm 0.31$ & Theora lubrica & $1.00 \pm 0.33$ & Theora lubrica & $1.00 \pm 0.31$ \\
\hline & Cossura sp. & $1.75 \pm 0.44$ & Aricidea sp. & $1.00 \pm 0.46$ & Ostracod sp. 1 & $1.00 \pm 0.61$ & Aricidea sp. & $1.00 \pm 0.41$ \\
\hline Sep & Theora lubrica & $2.50 \pm 0.60$ & Theora lubrica & $3.50 \pm 0.58$ & Phoxocephalidae & $3.50 \pm 0.81$ & Aricidea sp. & $3.25 \pm 0.78$ \\
\hline \multirow[t]{5}{*}{1996} & Boccardia syrtis & $1.50 \pm 0.60$ & Phoxocephalidae & $2.50 \pm 0.56$ & Aricidea sp. & $2.75 \pm 0.52$ & Phoxocephalidae & $3.00 \pm 1.99$ \\
\hline & Aricidea sp. & $1.25 \pm 0.57$ & Hemileucon sp. & $2.00 \pm 0.44$ & Phylo sp. & $2.00 \pm 0.51$ & Phylo sp. & $2.25 \pm 0.53$ \\
\hline & Phoxocephalidae & $1.00 \pm 0.71$ & Ostracod sp. 1 & $1.50 \pm 0.39$ & & & Gammaridae sp. 1 & $2.00 \pm 0.53$ \\
\hline & Ostracod sp. 4 & $1.00 \pm 0.42$ & Aricidea sp. & $1.50 \pm 0.34$ & & & & \\
\hline & Cossura sp. & $1.00 \pm 0.32$ & Boccardia syrtis & $1.50 \pm 0.45$ & & & & \\
\hline Mar & Talitridae & $4.00 \pm 1.34$ & Phoxocephalidae & $4.75 \pm 1.02$ & Theora lubrica & $3.00 \pm 0.39$ & Aricidea sp. & $3.75 \pm 0.83$ \\
\hline 1997 & Phoxocephalidae & $2.00 \pm 0.88$ & Boccardia syrtis & $3.00 \pm 0.38$ & Phoxocephalidae & $1.50 \pm 0.73$ & Cossura sp. & $1.75 \pm 0.34$ \\
\hline & Ostracod sp. 5 & $1.75 \pm 0.54$ & Aricidea sp. & $1.50 \pm 0.48$ & Cossura sp. & $1.00 \pm 0.28$ & Phoxocephalidae & $0.75 \pm 0.77$ \\
\hline & Arthritica bifurca & $1.25 \pm 0.49$ & Theora lubrica & $1.25 \pm 0.35$ & Arthritica bifurca & $0.75 \pm 0.29$ & Theora lubrica & $0.75 \pm 0.48$ \\
\hline & Aricidea sp. & $1.25 \pm 0.17$ & Cossura sp. & $1.00 \pm 0.38$ & Nucula spp. & $0.75 \pm 0.20$ & Ostracod sp. 1 & $0.75 \pm 0.19$ \\
\hline & Cossura sp. & $1.25 \pm 0.25$ & Paraonis sp. & $1.00 \pm 0.33$ & Aricidea sp. & $0.75 \pm 0.29$ & & \\
\hline Upper & r Harbour & & & & & & & \\
\hline Jan & Arthritica bifurca & $2.75 \pm 0.72$ & Boccardia syrtis & $3.50 \pm 1.54$ & Paraonis sp. & $3.00 \pm 0.71$ & & \\
\hline 1996 & Paraonis sp. & $2.25 \pm 0.97$ & Arthritica bifurca & $2.50 \pm 0.69$ & Boccardia syrtis & $2.75 \pm 0.66$ & & \\
\hline & Ostracod sp. 3 & $2.00 \pm 0.69$ & Nucula spp. & $1.75 \pm 0.64$ & Nucula spp. & $2.50 \pm 0.48$ & & \\
\hline & Phoxocephalidae & $1.50 \pm 0.79$ & Phoxocephalidae & $1.50 \pm 0.37$ & Arthritica bifurca & $2.25 \pm 0.62$ & & \\
\hline & Nucula spp. & $1.50 \pm 0.66$ & Paraonis sp. & $1.50 \pm 0.63$ & Ostracod sp. 3 & $2.00 \pm 0.48$ & & \\
\hline & Ostracod sp. 5 & $1.50 \pm 0.61$ & & & & & & \\
\hline
\end{tabular}


Table 3 (continued)

\begin{tabular}{|c|c|c|c|c|c|c|c|}
\hline \multirow{2}{*}{$\begin{array}{l}\text { Date } \\
\text { Sep }\end{array}$} & \multicolumn{2}{|c|}{ Control } & \multicolumn{2}{|c|}{ Low-density Atrina zelandica } & \multicolumn{2}{|c|}{ High-density A. zelandica } & \multirow[t]{2}{*}{ A. zelandica shell } \\
\hline & Boccardia syrtis & $8.25 \pm 1.44$ & Arthritica bifurca & $5.75 \pm 1.45$ & Arthritica bifurca & $5.25 \pm 0.81$ & \\
\hline \multirow[t]{4}{*}{1996} & Arthritica bifurca & $2.50 \pm 0.87$ & Boccardia syrtis & $4.25 \pm 0.94$ & Theora lubrica & $2.75 \pm 0.45$ & \\
\hline & Theora lubrica & $2.50 \pm 0.73$ & Phylo sp. & $3.75 \pm 0.56$ & Cossura sp. & $2.00 \pm 0.28$ & \\
\hline & Phoxocephalidae & $2.00 \pm 0.71$ & Theora lubrica & $3.00 \pm 0.63$ & Phylo sp. & $2.00 \pm 0.58$ & \\
\hline & Phylo sp. & $1.00 \pm 0.29$ & Aricidea sp. & $2.50 \pm 0.55$ & Paraonis sp. & $2.00 \pm 0.72$ & \\
\hline Mar & Arthritica bifurca & $4.75 \pm 1.06$ & Nucula spp. & $3.00 \pm 0.53$ & Theora lubrica & $6.75 \pm 0.94$ & \\
\hline \multirow{5}{*}{1997} & Theora lubrica & $3.25 \pm 0.64$ & Ostracod sp. 5 & $3.00 \pm 0.70$ & Arthritica bifurca & $5.00 \pm 1.63$ & \\
\hline & Paraonis sp. & $2.75 \pm 0.54$ & Phoxocephalidae & $2.00 \pm 0.40$ & Oligochaeta & $3.00 \pm 1.45$ & \\
\hline & Boccardia syrtis & $2.50 \pm 0.91$ & Theora lubrica & $2.00 \pm 0.59$ & Paraonis sp. & $2.25 \pm 0.77$ & \\
\hline & Phoxocephalidae & $1.50 \pm 0.34$ & Aricidea sp. & $1.50 \pm 0.52$ & Cossura sp. & $2.00 \pm 0.57$ & \\
\hline & Cossura sp. & $1.50 \pm 0.36$ & & & & & \\
\hline
\end{tabular}

Table 4. Summary table of significant treatment effects for most abundant taxa at each site. $\mathrm{C}=$ control $\left(0\right.$ Atrina zelandica $\left.\mathrm{m}^{-2}\right)$; $\mathrm{L}=$ low-density $\left(7.5 \mathrm{~A}\right.$. zelandica $\left.\mathrm{m}^{-2}\right) ; \mathrm{H}=$ high-density $\left(75 \mathrm{~A}\right.$. zelandica $\left.\mathrm{m}^{-2}\right)$. ns = not significant

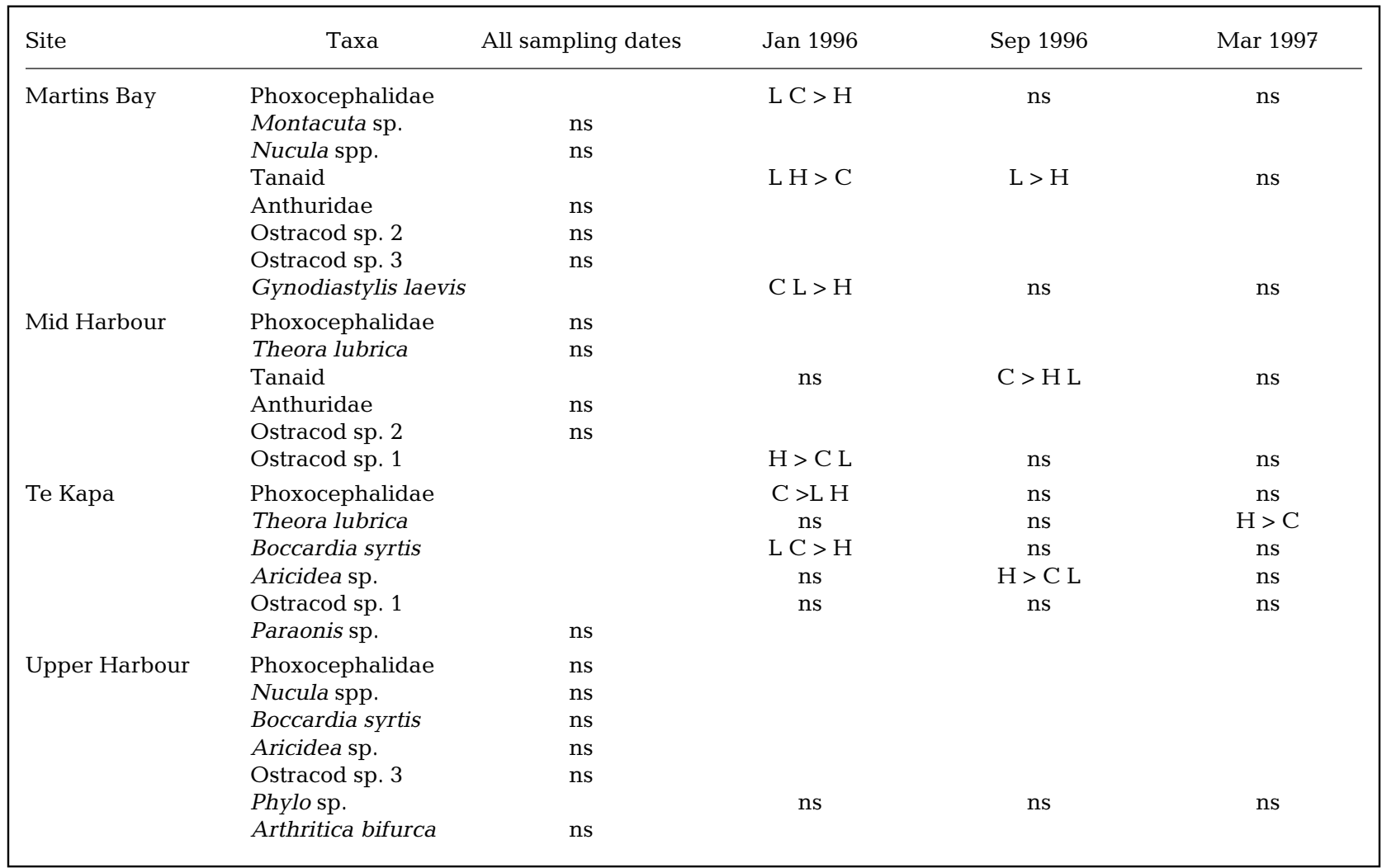

\section{Biological versus physical effects of Atrina zelandica}

Neither the number of individuals or the number of taxa found at the Te Kapa site were significantly different between the control, the high-density $A$. zelandica treatment or the $A$. zelandica shell treatment during the experiment (Table 5). When significant differences were detected between the live A. zelandica and $A$. zelandica shell treatments, more individuals were found amongst the shells. The one exception was the bivalve Theora lubrica, which showed the opposite pattern (Table 5).

\section{Explaining differences in macrobenthic community composition between sites using canonical correspondence analysis and multiple regression}

Initially, CCA and multiple regressions were run on the total data set, and interactions between site and 


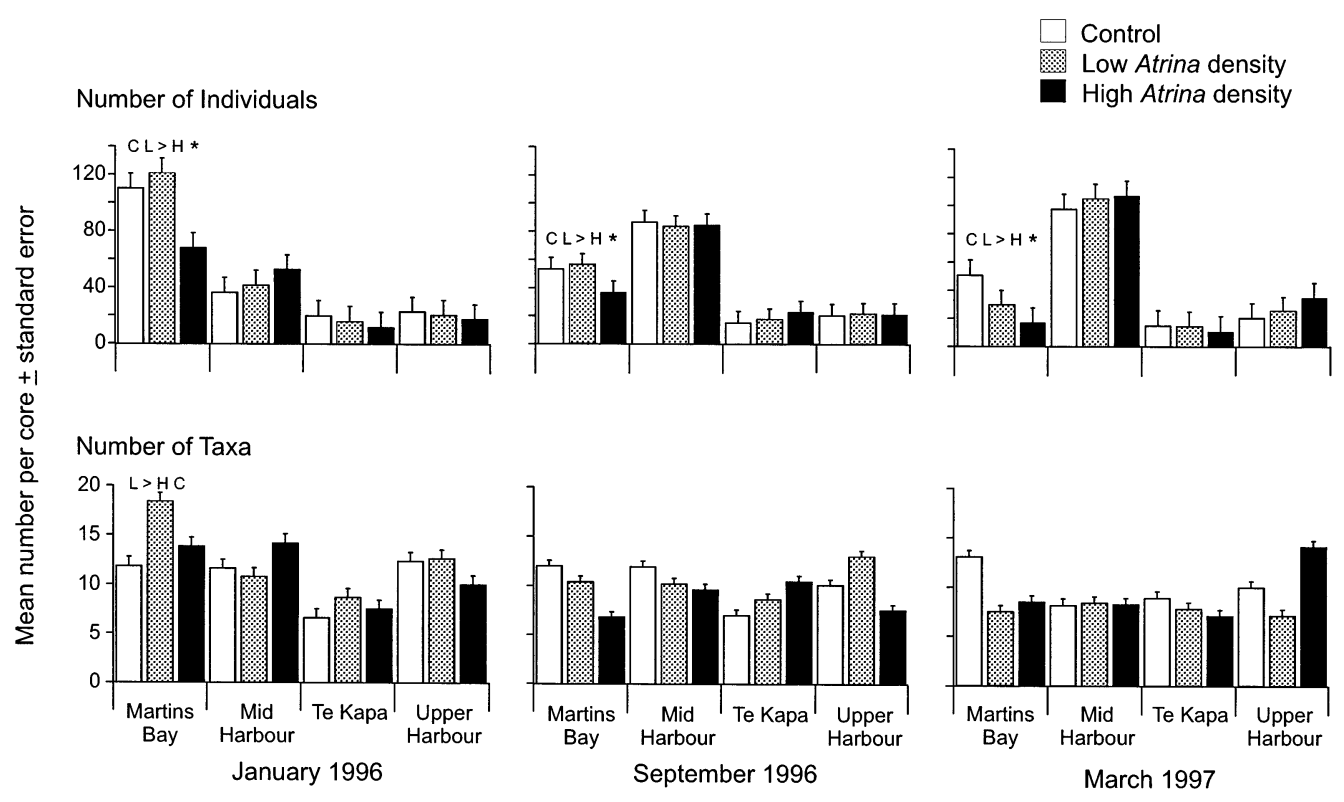

Fig. 4. Mean number of individuals and number of taxa at each site on each sampling date. Significant differences between treatments are also given: *indicates differences detected over all sampling dates. $\mathrm{C}=$ control $\left(0\right.$ Atrina zelandica $\left.\mathrm{m}^{-2}\right) ; \mathrm{L}=10 \mathrm{w}$-density $A$. zelandica treatment $\left(7.5 \mathrm{~A}\right.$. zelandica $\left.\mathrm{m}^{-2}\right) ; \mathrm{H}=$ high-density A. zelandica treatment $\left(75 \mathrm{~A}\right.$. zelandica $\left.\mathrm{m}^{-2}\right)$

date and the other covariables were included. However, only date interactions were found to be significant, usually between date and site, date and chlorophyll $a$, or date and horizontal turbulence. Therefore, CCAs and multiple regressions were run on each date separately. In all cases, there were no site interaction terms. Thus, inclusion of the covariables allowed to us to explore treatment effects that were consistent over all sites.

Table 5. Summary table of significant treatment effects for diversity indices, aggregate macrofauna groups, and most abundant taxa at Te Kapa. Abbreviations as in Table $4 . \mathrm{D}=$ Atrina zelandica shell $\left(75\right.$ shells $\left.\mathrm{m}^{-2}\right)$

\begin{tabular}{|c|c|c|c|c|}
\hline Factor & $\begin{array}{c}\text { Over all } \\
\text { dates }\end{array}$ & $\begin{array}{c}\text { Jan } \\
1996\end{array}$ & $\begin{array}{l}\text { Sep } \\
1996\end{array}$ & $\begin{array}{l}\text { Mar } \\
1997\end{array}$ \\
\hline Number of individuals & ns & & & \\
\hline Number of taxa & ns & & & \\
\hline Deposit feeders & ns & & & \\
\hline Suspension feeders & ns & & & \\
\hline Mobile spp. & & ns & $\mathrm{ns}$ & $\mathrm{C} \mathrm{D}>\mathrm{H}$ \\
\hline Short-lived spp. & & $\mathrm{C}>\mathrm{D} \mathrm{H}$ & ns & ns \\
\hline Long-lived spp. & ns & & & \\
\hline Phoxocephalids & & $\mathrm{C}>\mathrm{H}$ & ns & ns \\
\hline Theora lubrica & ns & & & $\mathrm{H}>\mathrm{C} \mathrm{D}$ \\
\hline Boccardia syrtis & & $\mathrm{C}>\mathrm{D} \mathrm{H}$ & ns & ns \\
\hline Aricidea sp. & & ns & $\mathrm{H}>\mathrm{C}$ & $\mathrm{D}>\mathrm{CH}$ \\
\hline Phylo sp. & $\mathrm{D}>\mathrm{HC}$ & & & \\
\hline Paraonis sp. & ns & & & \\
\hline Ostracod sp. 1 & $\mathrm{~ns}$ & & & \\
\hline
\end{tabular}

A maximum of $41 \%$ of the variation in macrofaunal community composition was explained by the environmental covariables (Table 6). Live Atrina zelandica, maximum velocity, water depth, sediment organic content and median grain size were important on each sampling date (Table 6). All of the covariables were important at some time during the experiment (Table 6).

The percentage of variation in the aggregate species groupings and diversity indices explained by the environmental co-variables was often higher than the community correspondence analysis (cf. Table 7 with Table 6). Over $20 \%$ of the variability in each factor was explained on most sampling dates (Table 7 ). The only 2 $\mathrm{R}^{2} \mathrm{~S}$ less than $10 \%$ were recorded in September 1996 (Table 7). The covariables most often important in explaining the variability were maximum velocity, water depth, median grain size and $A$. zelandica size (Table 7 ). The effect of horizontal turbulence and chlorophyll a was always to increase abundances each time they were included, while the remaining covariables were less consistent in their effects. For a particular diversity index/aggregate group, the combination of covariables explaining the variation was not consistent over time, 

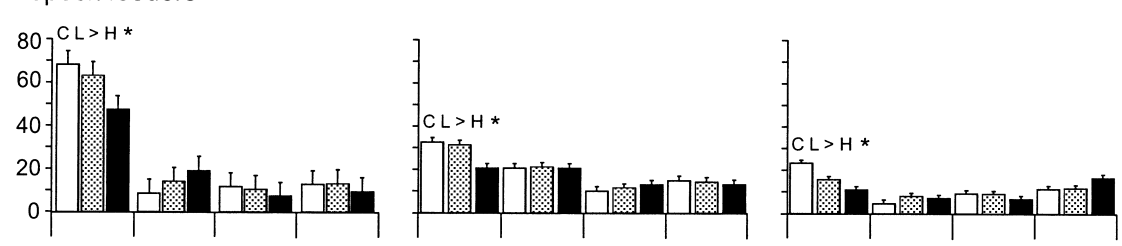

Suspension feeders
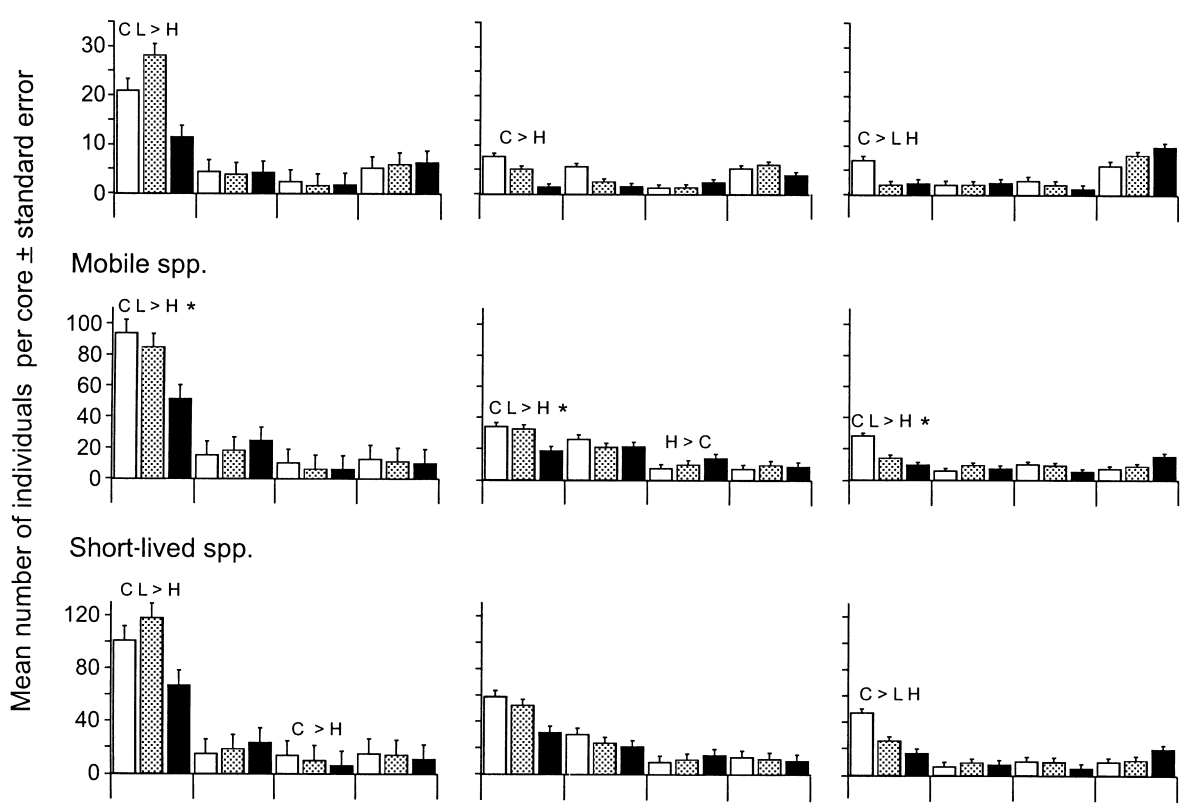

Mobile spp.
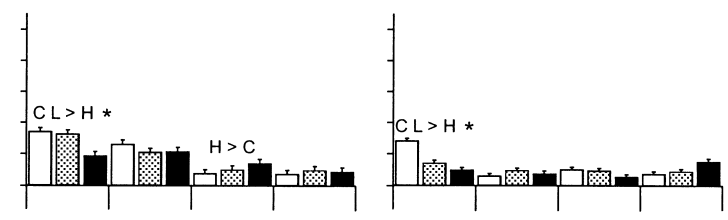

Long-lived spp
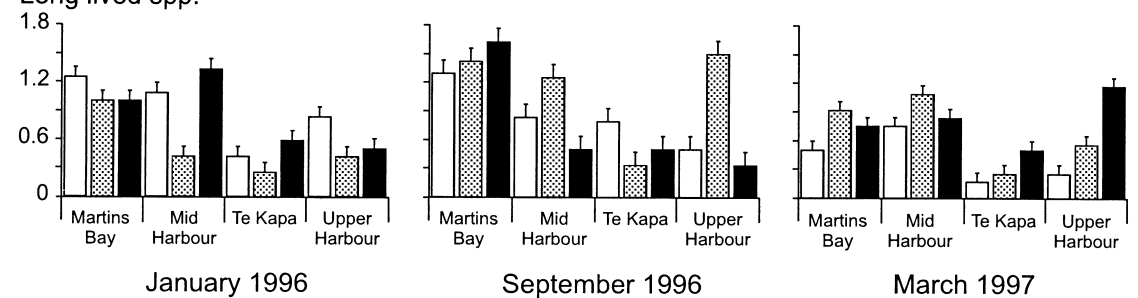

Fig. 5. Mean abundances of aggregate macrofauna groups at each site on each sampling date. Significant differences between treatments are also given: *indicates differences detected over all sampling dates. $\mathrm{C}=\mathrm{control}\left(0\right.$ Atrina zelandica $\left.\mathrm{m}^{-2}\right)$; $\mathrm{L}=$ low-density $A$. zelandica treatment $\left(7.5\right.$ A. zelandica $\left.\mathrm{m}^{-2}\right) ; \mathrm{H}=$ high-density $\mathrm{A}$. zelandica treatment $\left(75 \mathrm{~A}\right.$ zelandica $\left.\mathrm{m}^{-2}\right)$

although when a particular covariable was significant on more than 1 date, the sign of its effect was often the same (Table 7). For example, the percent variation explained for the total number of individuals was high on all sampling dates (i.e. $\mathrm{R}^{2}=0.66$ to 0.88 ), but the combination of important covariables varied with sampling date. Closer examination of the variables affecting the number of individuals in March 1997 shows the complexity of the interactions influencing their abundance: greater numbers of live A. zelandica, higher horizontal turbulence, plaster block erosion, maximum velocity and greater water depth all enhanced the numbers of individuals, while high roughness element densities, sediment organic content and drag coefficient all depressed them. Of these 8 covariables important in March 1997, only 4 (i.e. plaster block erosion, maximum velocity, water depth and drag coefficient) had also been important on a previous sampling date (Table 7). This example is typical of the regression results for the remaining diversity and aggregate macrofauna groupings (Table 7), and illustrates the complex interactions between A. zelandica and their environment which are determining macrofaunal abundances. 
Table 6. Results of canonical correspondence analysis investigating the relationship between macrofaunal community composition and environmental characteristics and aspects of Atrina zelandica over all sites on each sampling date. Chl $a=$ chlorophyll $a$

\begin{tabular}{|ccccccccccccc|}
\hline Date & $\begin{array}{c}\% \\
\text { explained }\end{array}$ & $\begin{array}{c}\text { A. } \\
\text { zelandica } \\
\text { size }\end{array}$ & $\begin{array}{c}\text { Live } \\
\text { A. } \\
\text { zelandica }\end{array}$ & Horizontal & turbulence & $\begin{array}{c}\text { Roughness } \\
\text { element } \\
\text { density }\end{array}$ & $\begin{array}{c}\text { Plaster } \\
\text { block } \\
\text { erosion }\end{array}$ & $\begin{array}{c}\text { Maximum } \\
\text { velocity }\end{array}$ & $\begin{array}{c}\text { Water } \\
\text { depth }\end{array}$ & $\begin{array}{c}\text { Chl a } \\
\text { organic } \\
\text { content }\end{array}$ & $\begin{array}{c}\text { Median } \\
\text { grain } \\
\text { size }\end{array}$ & $\begin{array}{c}\text { Drag } \\
\text { co- } \\
\text { efficient }\end{array}$ \\
\hline Jan 96 & 41 & $\mathrm{x}$ & $\mathrm{x}$ & $\mathrm{x}$ & $\mathrm{x}$ & & $\mathrm{x}$ & $\mathrm{x}$ & & $\mathrm{x}$ & $\mathrm{x}$ & $\mathrm{x}$ \\
Sep 96 & 38 & & $\mathrm{x}$ & $\mathrm{x}$ & $\mathrm{x}$ & & $\mathrm{x}$ & $\mathrm{x}$ & $\mathrm{x}$ & $\mathrm{x}$ & $\mathrm{x}$ & \\
Mar 97 & 30 & & $\mathrm{x}$ & & & & $\mathrm{x}$ & $\mathrm{x}$ & $\mathrm{x}$ & $\mathrm{x}$ & $\mathrm{x}$ & $\mathrm{x}$ \\
\hline
\end{tabular}

Table 7. Results of multiple regression investigating relationship between various factors (i.e. macrofaunal diversity indices and aggregate groups) and environmental characteristics and aspects of Atrina zelandica, over all sites on each sampling date. Direction of effect is given by + or - . Chl $a=$ chlorophyll $a$

\begin{tabular}{|c|c|c|c|c|c|c|c|c|c|c|c|c|c|}
\hline Factor & Date & $\begin{array}{c}\% \\
\text { explained }\end{array}$ & $\begin{array}{c}A . \\
\text { zelandica } \\
\text { size }\end{array}$ & $\begin{array}{c}\text { Live } \\
\text { A. } \\
\text { zelandica }\end{array}$ & $\begin{array}{l}\text { Horizontal } \\
\text { turbulence }\end{array}$ & $\begin{array}{c}\text { Roughness } \\
\text { element } \\
\text { density }\end{array}$ & $\begin{array}{l}\text { Plaster } \\
\text { block } \\
\text { erosion }\end{array}$ & $\begin{array}{l}\text { Maximum } \\
\text { velocity }\end{array}$ & $\begin{array}{l}\text { Water } \\
\text { depth }\end{array}$ & Chl a & $\begin{array}{c}\% \\
\text { organic } \\
\text { content }\end{array}$ & $\begin{array}{c}\text { Median } \\
\text { grain } \\
\text { size }\end{array}$ & $\begin{array}{c}\text { Drag } \\
\text { co- } \\
\text { efficient }\end{array}$ \\
\hline \multirow{3}{*}{$\begin{array}{l}\text { Number of } \\
\text { individuals }\end{array}$} & Jan 96 & 0.76 & & & & & - & + & + & + & & & \\
\hline & Sep 96 & 0.66 & + & & & & & + & + & & & & + \\
\hline & Mar 97 & 0.88 & & + & + & - & + & + & + & & - & & - \\
\hline \multirow{3}{*}{$\begin{array}{l}\text { Number of } \\
\text { taxa }\end{array}$} & Jan 96 & 0.18 & & & & & & + & + & & & & \\
\hline & Sep 96 & 0.09 & + & & & & & & & & & & \\
\hline & Mar 97 & 0.30 & - & + & + & & & - & & & & + & \\
\hline \multirow{3}{*}{$\begin{array}{l}\text { Deposit } \\
\text { feeders }\end{array}$} & Jan 96 & 0.60 & & & & & & & + & & - & & \\
\hline & Sep 96 & 0 & & & & & & & & & & & \\
\hline & Mar 97 & 0.25 & - & & + & & + & - & & & & & \\
\hline \multirow{3}{*}{$\begin{array}{l}\text { Suspension } \\
\text { feeders }\end{array}$} & Jan 96 & 0.62 & & - & & + & & - & & + & & + & \\
\hline & Sep 96 & 0.26 & + & - & & & - & - & - & & & & \\
\hline & Mar 97 & 0.32 & - & & + & & & - & - & & & + & \\
\hline \multirow{3}{*}{$\begin{array}{l}\text { Mobile } \\
\text { spp. }\end{array}$} & Jan 96 & 0.88 & & & + & - & & & + & & & + & - \\
\hline & Sep 96 & 0.60 & & & & & & & - & & & + & \\
\hline & Mar 97 & 0.40 & - & & + & & & - & & & & + & \\
\hline Short- & Jan 96 & 0.89 & & & + & - & & & + & + & & + & \\
\hline lived & Sep 96 & 0.66 & - & & & & & - & & & & + & + \\
\hline spp. & Mar 97 & 0.57 & - & & + & & & - & & & & + & \\
\hline Long- & Jan 96 & 0.34 & - & - & & + & & + & + & & & & \\
\hline lived & Sep 96 & 0.37 & & & & & & + & + & & + & - & \\
\hline spp. & Mar 97 & 0.24 & & & & + & & & & & & + & \\
\hline
\end{tabular}

\section{DISCUSSION}

This suspension-feeder density-manipulation experiment was designed to assess the influence of Atrina zelandica on local macrofaunal community composition. Our experiment incorporated a comparatively large spatial and temporal scale by being conducted in 4 different habitat types, each of which were separated by at least $1.75 \mathrm{~km}$, and by being sampled on 3 occasions over a 16 mo period. Based on previous work, we predicted stronger effects on overall community composition at sandy sites than at muddier sites (Prediction 1). Throughout the experiment, many more effects were observed at the sandiest site (Martins Bay) than at the remaining sites (Tables $2 \& 4$, Figs. 4 \& 5). Previous work had also suggested that numbers of macrofaunal individuals and taxa would be depressed amongst $A$. zelandica compared to sediments without $A$. zelandica patches (Prediction 2). While the numbers of individuals showed this pattern at 1 site only (Martins Bay), this prediction was not supported by the observed numbers of taxa (Fig. 4). We predicted that variability in hydrodynamic and sediment characteristics would help explain betweensite differences in the benthic community response to the density manipulation (Prediction 3). By including these environmental co-variables in our analysis, we observed a consistent response to A. zelandica across sites and significant amounts of variation in the response were explained for some macrofaunal groups (Tables 6 \& 7). However, both the amount explained, and the number and combinations of covariables which 
were important, differed with sampling date. Both biotic and abiotic co-variables were always important (Tables 6 \& 7 ).

We also predicted that different aggregate groups of macrofauna would respond to the Atrina zelandica density manipulation in different ways. We expected that deposit feeder and mobile species abundances would increase with increasing $A$. zelandica density (reflecting the higher food content due to $A$. zelandica biodeposits for both groups, and the added refuge from predators for mobile species) (Prediction 4). While this was true for mobile species at Te Kapa on 1 sampling date, the opposite pattern was observed for mobile species and deposit feeders at Martins Bay over all sampling dates (Fig. 5). We predicted that suspension-feeder abundance would decrease amongst $A$. zelandica, as a result of competing with these large bivalves for food (Prediction 5); this preference was shown at Martins Bay only (Fig. 5). Finally, we predicted that any responses by short-lived species (i.e. generation time $<1 \mathrm{yr}$ ) to A. zelandica density manipulations would be observed earlier than responses of long-lived species (i.e. generation time $>2 \mathrm{yr}$ ). A. zelandica significantly affected the abundance of short-lived species on the first and last sampling dates, while differences in the abundance of long-lived species had not been detected after 16 mo (Fig. 5).

Our results show that Atrina zelandica has significant effects on the associated macrobenthos, but that these effects are not spatially or temporally consistent. Whether or not a macrofaunal group responded to the presence of $A$. zelandica as we had predicted depended on the experimental site, and the time of sampling. This makes it difficult to generalise the specific effect of $A$. zelandica on macrofauna and to predict their likely effects at new sites. Our predictions were based on results of previous studies, which were conducted at small spatial and temporal scales and thus essentially examined local scale processes (see references below). At this local scale, enhanced abundances of some macrobenthic species around biogenic structures are well documented (e.g. Commito 1987 , Luckenbach 1984, Valentine \& Heck 1993, Tokeshi 1995, Dittman 1996, Creese et al. 1997, Crooks 1998, Ragnarsson \& Rafaelli 1999), but so are depressed abundances of other species (e.g. Luckenbach 1984, Commito 1987, Hines et al. 1989, Ragnarsson \& Raffaelli 1999). Our study suggests that this variation in experimental results is likely to be due to variations in environmental factors, species pools and the timing of experiments, rather than the specifics of different experimental designs. At the sandiest site, Martins Bay, the effect of $A$. zelandica was generally to reduce macrofaunal abundances. In other experiments where manipulations of suspension-feeding bivalves have reduced abundances of macrofauna, this pattern has been attributed to removal of planktonic larvae, or a combination of direct and indirect effects on recruitment (Commito 1987, Hines et al. 1989, Dittman 1990). As macrobenthos common amongst $A$. zelandica beds are not predominantly brooders (Cummings et al. 1998), the latter explanation, in combination with postsettlement processes (e.g. resource competition, predation, physical disturbance, sediment and biodeposit deposition) are more likely scenarios at this sandy site. In addition, as the ambient Martins Bay sediments contained the lowest \% organic content, \% clay and \% silt levels of all the experimental sites, it is possible that the presence of $A$. zelandica contributed to a more radical alteration of the local conditions relative to the other sites. Sebens \& McCoy (1991) predicted that mussel beds in particular should provide refuge for small mobile species which find prey amongst or adjacent to them. While this prediction has been supported by results at one site (Te Kapa) in our study, as well as by other studies (e.g. Svane \& Setyobudiandi 1996, Crooks 1998, Ragnarsson \& Raffaelli 1999), the opposite pattern was found at another site (Martins Bay) in this experiment (Fig. 5). Deposit feeders have also been found in higher abundances amongst mussel beds (e.g. Dittman 1990) and this has been suggested to be a response to enhanced deposition of sediment and biodeposits. In our experiment, depositfeeder densities were lower when associated with $A$. zelandica at Martins Bay (Fig. 5). Some experiments have incorporated 'mimics' to help distinguish the effects of live bivalves from the physical presence of their shells (e.g. Crooks \& Khim 1999). The A. zelandica shell treatment, although included at only 1 site, reflected the macrofauna response exhibited in the main experiment. For many of the macrofauna taxa and groups tested, there was no difference between macrofaunal abundances in the A. zelandica shell and the live $A$. zelandica treatments (e.g. numbers of deposit feeders or suspension feeders). When differences were detected between these 2 treatments, macrofauna abundances were generally higher in the dead shell treatment (Table 5). As both of these treatments had $A$. zelandica shells modifying benthic boundary flow, it suggests some biotic action by the live A. zelandica is inducing a negative response. It also suggests a positive response to the shelter provided by the empty shells.

This variability of our experimental results over time illustrates the complexity of the interactions between Atrina zelandica and their environment which are influencing macrofaunal abundances. Given the differences in benthic communities and physical characteristics between sites, we expected our experiment to take a few months to reveal consistent community 
effects. Thus, the experiment was continued for $16 \mathrm{mo}$, to ensure it encompassed macrofauna recruitment events. Differences in macrofaunal community composition between treatments at a site were generally greater on the last sampling date (March 1997) than earlier in the experiment (Fig. 3), suggesting that local habitat modification by $A$. zelandica takes a considerable length of time to influence the overall macrofaunal community, probably as a result of seasonal recruitment events. The effects of this experiment were stronger on the summer sampling occasions (i.e. January 1996 and March 1997) than in September 1996, again suggesting a recruitment response. Thus, if this study had only been run for 10 mo and sampled in September, the conclusions drawn would have been different due to lower numbers (and levels) of significant results (e.g. Table 7). It is possible that our experimental effects would have been less variable had we continued the experiment for longer than 16 mo and included another sampling occasion. However, indirect effects in manipulative experiments generally appear around the same time as any direct effects (Menge 1997), so this may not have affected our results, suggesting that these results are not just experimental artefacts.

Considerable variation in macrofaunal abundance has also been noted among natural Atrina zelandica patches (i.e. Cummings et al. 1998, Hewitt et al. unpubl. data). While we were sometimes able to explain large amounts of the variation in this experiment, as mentioned previously, the covariables important were not consistent over time (Table 7). Thus, we were not able to identify a single process associated with A. zelandica, or even a consistent combination of several processes, as having a more important influence over macrobenthic communities. All of the covariables related to A. zelandica were important on some sampling date, but none appeared to be more so than the others. Water depth and maximum velocity were the most important physical covariables in this experiment. However, more consistent responses over time were found for the community analyses than for the aggregate macrofauna groups (cf. Tables 6 \& 7), with density of live $A$. zelandica, maximum velocity, water depth, \% organic content and median grain size all being important on every sampling date (Table 6).

Atrina zelandica certainly has all the attributes of a species which directly/indirectly structures communities (i.e. it is large, forms dense and large patches, affects flow conditions, suspension feeds and produces biodeposits) and our experiment shows this bivalve does significantly influence macrofaunal communities. Variability in experimental results with spatial and temporal scale of sampling and also with habitat type (e.g. Chapman \& Underwood 1998) is now well recog- nised, and researchers are aware of the limitations of conducting small-scale, single site/time experiments. To be able to generalise results, larger scale experiments, conducted at more than 1 site and at more than 1 time, are generally considered preferable. Despite our A. zelandica manipulation experiment having these attributes, the results have not enabled us to better predict the influence of this large suspension feeder on the associated macrofaunal community, except perhaps in sandy, relatively non-tidal environments. However, we were able to demonstrate that interactions between $A$. zelandica, hydrodynamic conditions and sediment characteristics were all important in influencing macrofauna, rather than there being a simple A. zelandica density-macrofauna relationship. Indeed, our experiment has proved to be a good example of how experimental results can vary with habitat type and time of sampling and illustrates our limited success in 'reducing' the complexity of this system using a field experiment. Thus, where multi-species interactions, indirect effects, non-linear biotic/abiotic interactions and threshold effects play an important role (e.g. Kneib 1988, Posey 1990, Wootton 1994), specific experiments may not alone lead to generalisable results, simply because the system is too complex.

Acknowledgements. This experiment would not have been possible without the invaluable field support provided by Rod Budd, Andy Hill, Carly Milburn, Terry Hume and Stephanie Turner. Carly Milburn, John Hawken and Karen Burt helped with sample processing. Bob Whitlatch, an anonymous reviewer, and Alf Norkko made valuable comments on an earlier manuscript. This research was made possible by support from FRST-CO1211.

\section{LITERATURE CITED}

Black R, Peterson CH (1988) Absence of pre-emption and interference competition for space between large suspension-feeding bivalves and smaller infaunal macroinvertebrates. J Exp Mar Biol Ecol 120:183-193

Chapman MG, Underwood AJ (1998) Inconsistency and variation in the development of rocky intertidal algal assemblages. J Exp Mar Biol Ecol 224:265-289

Clarke KR (1993) Non-parametric multivariate analyses of changes in community structure. Aust J Ecol 18:117-143

Commito JA (1987) Adult-larval interactions: predictions, mussels and cocoons. Estuar Coast Shelf Sci 25:599-606

Commito JA, Boncavage EM (1989) Suspension-feeders and coexisting infauna: an enhancement counterexample. J Exp Mar Biol Ecol 125:33-42

Commito JA, Thrush SF, Pridmore RD, Hewitt JE, Cummings VJ (1995) Dispersal dynamics in a wind-driven benthic system. Limnol Oceanogr 40:1513-1518

Crawley MJ (1993) GLIM for ecologists. Blackwell Scientific Publications, Oxford

Creese R, Hooker, S, DeLuca, S, Wharton, W (1997) Ecology and environmental impact of Musculista senhousia (Mol- 
lusca: Bivalvia: Mytilidae) in Tamaki Estuary, Auckland, New Zealand. NZ J Mar Freshw Res 31:225-236

Crooks JA (1998) Habitat alteration and community-level effects of an exotic mussel, Musculista senhousia. Mar Ecol Prog Ser 162:137-152

Crooks JA, Khim HS (1999) Architectural vs. biological effects of a habitat altering exotic mussel, Musculista senhousia. J Exp Mar Biol Ecol 240:53-75

Cummings VJ, Thrush SF, Hewitt, JE, Turner, SJ (1998) The influence of the pinnid bivalve Atrina zelandica (Gray) on benthic macroinvertebrate communities in soft-sediment habitats. J Exp Mar Biol Ecol 228:227-240

Dame RF (ed) (1992) Bivalve filter feeders in estuarine and coastal processes. NATO ASI (Ser G: Ecol Sci) 33:1-579

Dayton PK, Tegner MJ, Parnell PE, Edwards PB (1992) Temporal and spatial patterns of disturbance and recovery in a kelp forest community. Ecol Monogr 62:421-445

Dayton PK, Tegner MJ, Edwards PB, Riser KL (1999) Temporal and spatial scales of kelp demography: the role of oceanographic climate. Ecol Monogr 69:219-250

Dittman S (1990) Mussel beds - amensalism or amelioration for intertidal fauna? Helgol Meeresunters 44:335-352

Dittman S (1996) Effects of macrobenthic burrows on infaunal communities in tropical tidal flat. Mar Ecol Prog Ser 134: $119-130$

Eckman JE (1983) Hydrodynamic processes affecting benthic recruitment. Limnol Oceanogr 28:241-257

Graf G (1999) Do benthic animals control the particle exchange between bioturbated sediments and benthic turbidity zones? In: Gray JS, Ambrose W, Szaniawska A (eds) Biogeochemical cycling and sediment ecology. Kluwer Academic, Dordrecht, p 153-160 (NATO ASI Ser E: Appl Sci 59:153-160)

Graf G, Rosenberg R (1997) Bioresuspension and biodeposition: a review. J Mar Syst 11:269-278

Green MO, Hewitt JE, Thrush SF (1998) Seabed drag coefficient over natural beds of horse mussels (Atrina zelandica). J Mar Res 56:613-637

Hill MO (1979) DECORANA: a FORTRAN program for detrended correspondence analysis and reciprocal averaging. Section of Ecology and Systematics, Cornell University, Ithaca, NY

Hines AH, Posey MH, Haddon PJ (1989) Effects of adult suspension- and deposit-feeding bivalves on recruitment of estuarine infauna. Veliger 32:109-119

Howerton RD, Boyd CE (1992) Measurement of water circulation in ponds with gypsum blocks. Aquacult Engr 11: $141-155$

Hunt JH, Ambrose WG, Peterson CH (1987) Effects of the gastropod, Ilyanassa obsoleta (Say), and the bivalve, Mercenaria mercenaria (L.), on larval settlement and juvenile recruitment of infauna. J Exp Mar Biol Ecol 108:229-240

Irlandi EA (1996) The effects of seagrass patch size and energy regime on growth of a suspension feeding bivalve. J Mar Res 54:161-185

Irlandi EA, Ambrose WG, Orlando BA (1995) Landscape ecology and the marine environment: how spatial configuration of seagrass habitat influences growth and survival of the bay scallop. Oikos 72:307-313

Keddy PA (1991) Working with heterogeneity: an operator's guide to environmental gradients. In: Kolasa J, Pickett STA (eds) Ecological heterogeneity. Springer-Verlag, New York, p 181-201

Klerks PL, Fraleigh PC, Lawniczak JE (1996) Effects of zebra mussels (Dreissena polymorpha) on seston levels and sediment deposition in western Lake Erie. Can J Fish Aquat Sci 53:2284-2291
Kneib RT (1988) Testing for indirect effects of predation in an intertidal soft-bottom community. Ecology 69:1795-1805

Legendre P, Anderson MJ (1999) Distance-based redundancy analysis: testing multi-species responses in multi-factorial ecological experiments. Ecol Monogr 69:1-24

Levin SA (1988) The problem of pattern and scale in ecology. Ecology 73:1943-1967

Luckenbach MW (1984) Settlement and early post-settlement survival in the recruitment of Mulinia lateralis (Bivalvia). Mar Ecol Prog Ser 17:245-250

McCullagh P, Nelder JA (1989) Generalised linear models. Chapman \& Hall, London

Menge BA (1997) Detection of direct versus indirect effects: were experiments long enough? Am Nat 149:801-823

Micheli F (1997) Effects of predator foraging behavior on patterns of prey mortality in marine soft bottoms. Ecol Monogr 67:203-224

Morton JE, Miller MC (1968) The New Zealand sea shore. William Collins Sons \& Co, Glasgow

Nowell ARM, Church M (1979) Turbulent flow in a depthlimited boundary layer. J Geophys Res 84:4816-4824

Olafsson EB, Peterson CH, Ambrose WG (1994) Does recruitment limitation structure populations and communities of macro-invertebrates in marine soft-sediments: the relative significance of pre- and post-settlement processes. Oceanogr Mar Biol Annu Rev 32:65-109

Peterson BJ, Heck KL (1999) The potential for suspension feeding bivalves to increase seagrass productivity. J Exp Mar Biol Ecol 240:37-52

Peterson CH, Black R (1993) Experimental tests of the advantages and disadvantages of high density for two coexisting cockles in a Southern Ocean lagoon. J Anim Ecol 62: 614-633

Posey MH (1990) Functional approaches to soft-substrate communities: how useful are they? Rev Aquat Sci 2: 343-356

Powell AWB (1979) New Zealand Mollusca. Marine, land and freshwater shells. William Collins, Auckland

Prins TC, Smaal AC, Pouwer AJ, Dankers N (1996) Filtration and resuspension of particulate matter and phytoplankton on an intertidal mussel bed in the Oosterschelde estuary (SW Netherlands). Mar Ecol Prog Ser 142:121-134

Raffaelli D, Moller H (1999) Manipulative field experiments in animal ecology: do they promise more than they can deliver? Adv Ecol Res 30:299-338

Ragnarsson SA, Raffaelli D (1999) Effects of the mussel Mytilus edulis L. on the invertebrate fauna of sediments. J Exp Mar Biol Ecol 241:31-43

Sartory DP (1982) Spectrophotometric analysis of chlorophyll a in freshwater phytoplankton. Hydrological Research Institute, Pretoria (Tech Rep TR 115)

SAS/Insight (1993) Users' guide. Version 6. SAS Institute Inc, Cary, NC

Sebens KP, McCoy ED (1991) Habitat structure and community dynamics in marine benthic systems. In: Bell SS, McCoy ED, Mushinsky HR (eds) Habitat structure: the physical arrangement of objects in space. Chapman \& Hall, London, p 211-234

Svane I, Setyobudiandi I (1996) Diversity of associated fauna in beds of the blue mussel Mytilus edulis L.: effects of location, patch size, and position within a patch. Ophelia 45: 39-53

ter Braak CJF (1986) Canonical correspondence analysis: a new eigenvector technique for multivariate direct gradient analysis. Ecology 67:1167-1179

ter Braak CJF, Prentice IC (1988) A theory of direct gradient analysis. Adv Ecol Res 18:271-317 
ter Braak CJF, Verdonschot PFM (1995) Canonical correspondence analysis and related multivariate methods in aquatic ecology. Aquat Sci 57:153-187

Thompson TL, Glenn EP (1994) Plaster standards to measure water motion. Limnol Oceanogr 39:1768-1779

Thrush SF, Hewitt JE, Pridmore RD, Cummings VJ (1996) Adult/juvenile interactions of infaunal bivalves: contrasting outcomes in different habitats. Mar Ecol Prog Ser 132: $83-92$

Thrush SF, Pridmore RD, Bell RG, Cummings VJ, Dayton PK, Ford R, Grant J, Hewitt JE, Hines AH, Hume TM, Lawrie SM, Legendre P, McArdle BH, Morrisey D, Schneider DC, Turner SJ, Walters R, Whitlatch RB, Wilkinson MR (1997a) The sandflat habitat: scaling from experiments to conclusions. J Exp Mar Biol Ecol 216:1-9

Thrush SF, Schneider DC, Legendre P, Whitlatch RB, Dayton PK, Hewitt JE, Hines AH, Cummings VJ, Lawrie SM, Grant J, Pridmore RD, Turner SJ (1997b) Scaling-up from experiments to complex ecological systems: where to next? J Exp Mar Biol Ecol 216:243-254

Thrush SF, Hewitt JE, Cummings VJ, Green MO, Funnell GA, Wilkinson MR (2000) Improving the generality of field experiments: the interaction of processes operating over different spatial scales on intertidal sandflats. Ecology 81: $399-415$

Tokeshi M (1995) Polychaete abundance and dispersion patterns in mussel beds: a non-trivial 'infaunal' assemblage

Editorial responsibility: John Gray (Contributing Editor), Oslo, Norway on a Pacific South American rocky shore. Mar Ecol Prog Ser 125:137-147

Valentine JF, Heck KL (1993) Mussels in seagrass meadows: their influence on macroinvertebrate abundance and secondary production in the northern Gulf of Mexico. Mar Ecol Prog Ser 96:63-74

Verdonschot PFM, ter Braak CJF (1994) An experimental manipulation of oligochaete communities in mesocosms treated with chlorpyrifos or nutrient additions: multivariate analyses with Monte Carlo permutation tests. Hydrobiologia 278:251-266

Warwick RM, McEvoy AJ, Thrush SF (1997) The influence of Atrina zelandica Gray on nematode diversity and community structure. J Exp Mar Biol Ecol 214:231-247

Wiens JA, Rotenberry JT, van Horne B (1986) A lesson in the limitations of field experiments: shrubsteppe birds and habitat alteration. Ecology 67:365-376

Witte U, Brattegard T, Graf G, Springer B (1997) Particle capture and deposition by deep-sea sponges from the Norwegian-Greenland Sea. Mar Ecol Prog Ser 154:241-252

Woodin SA (1983) Biotic interactions in recent marine sedimentary environments. In: Tevesz JS, McCall PL (eds) Biotic interactions in recent and fossil benthic communities. Plenum Publishing Corporation, New York, p 3-38

Wootton JT (1994) The nature and consequences of indirect effects in ecological communities. Annu Rev Ecol Syst 25: 443-466

Submitted: May 15, 1999; Accepted: June 8, 2000 Proofs received from author(s): November 27, 2000 